\title{
Legalization and Human Capital Accumulation
}

\author{
Fabio Méndez* \\ Loyola University Maryland Universidad de Santiago de Chile
}

\author{
Nieves Valdés \\ Universidad Adolfo Ibáñez.
}

January 5, 2015

\begin{abstract}
This paper presents new evidence regarding the effects of legalization on the training of immigrants who were granted legal status through the U.S. Immigration Reform and Control Act (IRCA) of 1986. Our findings point to a large increase in the immigrants' incidence of training relative to comparable groups of natives following legalization and also to significant gains in the quality of occupations held by legalized immigrants. The estimations are conducted using a difference in differences approach, which identifies the effects of legalization separately from those of time and unobserved individual characteristics. The results are robust to changes in the treatment and control groups used for the analysis. JLE O15
\end{abstract}

*Corresponding author, email: fmendez1@loyola.edu, phone: 4796175754. We wish to thank Carolina Concha for expert research assistance. All errors are ours. 


\section{Introduction}

The large number of illegal immigrants living in the US has motivated ample public debate, but little legislative work, over the years. In fact, the 1986 Immigration Reform and Control Act (IRCA), which is perhaps the most salient of all recent immigration reforms, is now almost 30 years old. Since IRCA was implemented, the number of illegal workers living inside the USA is thought to have increased to more than twice what it was back in 1986 (see, e.g., Smith and Edmonson (1997) and Passel et al (2013)) and political debates have stalled between proposals for stricter law enforcement on one end and for providing illegal aliens with a path to citizenship on the other. ${ }^{1}$

Part of the problem is that the economic consequences of such legalization (or antilegalization) initiatives cannot be fully assessed without a proper understanding of how they affect the productivity of the legalized population, and the literature that addresses this matter is relatively scant. Most of the papers in this literature, look at the effects of legalization on the wages of the legalized population. Rivera-Batiz (1999), for example, finds wage gains of $13 \%$ for males and $17 \%$ for females as a result of IRCA. Kossoudji and Cobb-Clark (2002) and Amuedo-Dorantes et al. (2007) also focus on IRCA and find comparable wage gains after legalization of $4 \%$ and $9 \%$, respectively. Kaushal (2006), in turn, reports wage gains for Central American immigrants legalized under the 2006 Nicaraguan Adjustment and Central American Relief Act (NACARA) that range between 0\% to 5\%, depending on country of origin and educational level. ${ }^{2}$

But while the evidence on wage gains suggests legalization generates an immediate positive effect on the wellbeing of the legalized individuals, it fails to capture the long term socio economic effects that legalization may also have on the productivity of those individuals and the welfare of society in general. Legalization allows immigrants to choose among an ex-

\footnotetext{
${ }^{1} \mathrm{~A}$ proposal to provide a path to citizenship for an estimated 11 million illegal workers is currently stalled in congress. This proposal is available at www.whitehouse.gov/issues/immigration.

${ }^{2}$ Sampaio et al (2013) argues the evidence on wage gains following legalization is not robust to a modest amount of correlation between unobserved immigrant characteristics and unobserved wage determinants.
} 
panded set of occupations and provides them with incentives to learn new skills that qualifies them for jobs with higher remuneration. Thus, an important part of the gains generated by legalization are not likely to be realized in the form of immediate wage gains, but rather in the form of human capital investments.

In this paper, we depart from the existing literature and examine how legalization induces workers to engage in the acquisition of new skills via training. Increased skill accumulation could be the most important change brought about by legalization in the long run. Not only it is at the base of increased wages and material well being, but it is also tied to a number of desirable socio economic outcomes, such as lower criminal behavior, lower teenage pregnancy, and better child health, among others. In addition, the effects of legalization on skill accumulation are a key complement to a related literature that studies the net effects of migration on a variety of economic variables. In that literature, the effects of migration are shown to depend pivotally on whether or not the immigrants' human capital catches up or "assimilates" over time to that of natives; with greater assimilation usually tied to better outcomes (see, for instance, Chiswick (1980), Dolado et al. (1994), and Borjas (1995)).

Admittedly, training is not an exhaustive account of all human capital accumulation activities, but it is arguably the most important channel through which individuals accumulate skills after they enter the job market (see Méndez and Sepulveda 2012 for a comparison of workers' training and formal education in the NLSY79). Our claim is that skill accumulation via training provides a good indication of the overall changes in human capital experienced by legalized immigrants.

To conduct our study, we utilize data from the US Legalized Population Survey (LPS) on the training experiences of immigrants legalized through IRCA, before and after legalization, and compare their training outcomes to those of various groups of natives drawn from the 1979 National Longitudinal Survey of Youth (NLSY79) using a difference-in-differences specification similar to that used by Kossoudji and Cobb-Clark (2002). This approach allows us to identify the effects of legalization separately from those of time and unobserved 
individual characteristics.

Our results provide strong evidence that legalization affects the incidence of training positively. After legalization has taken place, immigrants in our sample become more likely to receive training than comparable groups of natives, and the difference is economically, as well as statistically significant. The relative gains are higher for men (11 percentage points increase) than they are for women (4 percentage points increase), and they are higher for those with a high school degree (13 percentage points increase) than for those without (3 percentage points increase, not significant). All results are robust to changes in the composition of both the control and treatment groups used.

At first glance, these findings seem to be at odds with two previous papers by RiveraBatiz (1999) and Kossoudji and Cobb-Clark (2002). These papers find legalization has a positive effect on earnings, which is consistent with our results (assuming training increases productivity). But they also find the effect on wages is smaller for men than it is for women, which does not seem consistent with our findings that men experience larger increases in their human capital after legalization. A closer look, however, reveals our findings are well aligned with those of Rivera-Batiz (1999) and Kossoudji and Cobb-Clark (2002), for their work suggests most of the short-run wage increases experienced by legalized workers result from gains in their occupational mobility and not from gains in their human capital stock.

We corroborate the findings of Rivera-Batiz (1999) and Kossoudji and Cobb-Clark (2002) with respect to the effects of legalization on wages. In our own estimations all immigrants experienced an increase in their wages as the result of legalization, with a greater increase for women than for men. At the same time, we find evidence that legalization indeed altered the occupational choices of legalized men and women differently. After legalization takes place, all immigrants in our sample moved to better occupations (occupations with higher average pay) relative to comparable groups of natives, but the relative improvement was found to be greater for women than it was for men.

Our finding that women experience greater increases occupational quality after legaliza- 
tion (relative to men) is fully consistent with the finding that women experience greater increases in their wages after legalization (relative to men) and may help explain why training and wages do not go hand in hand. This finding also opens a new set of questions related to why women react differently than men to the incentives provided by legalization in terms of both, their short term employment choices and long term investments in human capital.

The remaining of the paper is organized as follows: Section 2 describes the data. Section 3 describes the empirical methodology and presents the results. Section 4 concludes.

\section{Data Description}

The U.S. Immigration Reform and Control Act (IRCA) is the largest legalization initiative in US history. It was comprised by two separate legalization programs: The General Legalization Program, which affected about 1.8 million individuals, and the Special Agricultural Workers Program (SAW), which affected about 1.3 million individuals. A national representative sample of those who successfully obtained legal permanent residence through the General Legalization Program was interviewed twice by the Legal Population Surveys (LPS). Individuals who applied for legal residence under SAW were not interviewed.

Under the General Legalization program, illegal aliens had to demonstrate continuous residence since at least January 1, 1982 and apply for legal residency sometime between January 1987 and December 1988. Upon completion of the initial application, they were granted temporary legal status and were given 18 months to complete a subsequent application for permanent legal status which required an english test. A total of 1.8 million individuals initially qualified for temporary legal residence, but only 1.6 million successfully completed the process for permanent residency. From these 1.6 million, a random sample of 6,193 individuals was interviewed in the first LPS survey (LPS1), which was conducted between February and June of 1989; just one month after immigrants had obtained their temporary legal status. The survey asked respondents about their experiences before arriving to the 
USA and during their illegal stay in the country.

Approximately 3 years later, between April and September of 1992, a total of 4,012 individuals from the original sample were re-interviewed in the second LPS survey (LPS2). Most of the attrition in the LPS is due to loss of contact. The LPS2 interviews started right after the deadline for completing their permanent residence application process had expired and the individuals had obtained permanent legal status. It asked respondents about their labor market experience since the first LPS1 survey -a time at which they had obtained temporary legal status- including their participation in on-the-job training programs.

We utilize the data from the LPS surveys to study the training experienced by legalized immigrants, before and after legalization. The first period of interest, the pre-legalization period, is defined as the time elapsed from the date of arrival to the US to the date of initial application to IRCA (both of these dates were recorded in the LPS). This is the period of time during which the individual resided in the USA illegally. Its duration varies by individual, depending on the specific dates of arrival and application for residency. The second period of interest, the post-legalization period, is defined as the time elapsed from the date of initial application to the date of the second interview. This is a period of about 3 years (we have no information on the month of the second interview) in which the individuals resided legally in the USA.

We are mainly interested in tracking changes in the accumulation of human capital via training between the pre-legalization and the post-legalization periods. For that purpose, we construct an indicator variable labeled training. For both periods, this variable takes a value equal to one if the individual received any training in the period and zero other wise. Further detail on the extent or duration of training was not recorded in the LPS. Other variables obtained from the LPS surveys included the hourly wage rates in the jobs held at interview times expressed in current dollars (wage), a gender indicator for males (male), the individual's age at the time of the interviews (age), and an indicator for having a high school diploma at the time of interview (hschool). 
To assess the effects of legalization on human capital formation, it would be ideal to compare the observed experiences of legalized individuals to those of a control group of randomly selected individuals who were not allowed to participate in the legalization program and remained in the US in conditions similar to those prevailing before IRCA, but who were otherwise identical to the legalized population. This ideal control group is unavailable, since the reform enacted by IRCA affected all unauthorized workers at the time and established a new set of penalties for employers of illegal immigrants. Instead, following the work of Kossoudji and Cobb-Clark (2002) and Amuedo-Dorantes et al. (2007), we utilize a comparison group of legal workers selected from respondents of the National Longitudinal Survey of Youth (NLSY79).

The information in the NLSY79 is rich enough for us to reconstruct the same set of variables constructed with the LPS survey; except, of course, for the variables containing the date of arrival to the USA and the dates of application for legal residency. ${ }^{3}$ As explained before, these dates vary across individuals in the LPS and, as a result, the pre and post legalization periods have different lengths for each person. This is important for constructing comparable measures of training in the NLSY, since the periods of time over which training incidence is measured need to be comparable across samples ${ }^{4}$. In order to construct comparable periods in the NLSY, we generate synthetic dates of arrival, application, and second interview for each individual in that survey. We first set a "date of arrival" equal to January 1982 (equal to the actual dateline set by IRCA), then a "date of second interview" equal to May 1992, and finally a randomly generated "date of application", for which we use the empirical probability density function of this date from the LPS sample. These choices ensure that both periods are similar in duration across groups.

The NLSY79 consists of 12,686 individuals who are first interviewed in 1979. We merged the information from the NLSY79 with that of the 6,193 LPS respondents. From that, we

\footnotetext{
${ }^{3}$ Wages in the NLSY79 were censored above 1,000 and below 0.5 , which affected 5 observations in the NLSY sample, despite which a few very high values remain.

${ }^{4}$ In the appendix, we report the exact questions from the LPS and NLSY surveys that were used to construct the training indicator variables.
} 
drop individuals who were not interviewed in the 1988, 1989 or 1992 waves of the NLSY (4,243 individuals) or in the second wave of the LPS (2,181 individuals). We further drop individuals who had reached retirement age by 1992 (161 individuals), who belonged to the military subsample of the NLSY79 (161 individuals), and those with incomplete information on training, age, gender, or high school completion (11 individuals). We are left with 8,244 NLSY and 3,909 LPS respondents.

In order to ensure the comparison and treatment groups are as similar as possible, our baseline results were obtained using a subsample of Mexican and Central American immigrants from the LPS (2,874 individuals) and a comparison sample of hispanics from the NLSY79 (1,577 individuals). The baseline dataset then consists of 8,902 observations on 4,451 individuals. For robustness purposes, however, the results were also obtained using three alternative comparison groups composed of all NLSY79 respondents, all NLSY79 Hispanics of low socio-economic status, and subset of NLSY79 immigrants, respectively. In addition, given that the range in ages is greater in the LPS than in the NLSY79, we also present results of estimations for which the LPS sample was censored so that the respondents age range matched that of the NLSY79.

To complete the dataset, we construct a measure of occupational quality. This measure is the average hourly wage earned by occupation (wage-occup), expressed in 1990 dollars. The data necessary to compute this average was obtained from the 1990 census public files and merged using the 3-digit occupational codes. A preliminary analysis of the differences in the main variables is provided below. Additional descriptive statistics for other relevant variables are provided in Table 7 in the appendix.

\subsection{Preliminary Analysis}

We begin by comparing the means of our three outcomes of interest (training, wages, and occupational quality), before and after legalization, for immigrants and natives. Given that women are more likely to stay at home than men, we can expect the effects of legalization 
on decisions to train and work to be different across men and women. For this reason, all mean comparisons are disaggregated by gender.

Figure 1: Mean of Training by sample, gender, and period.

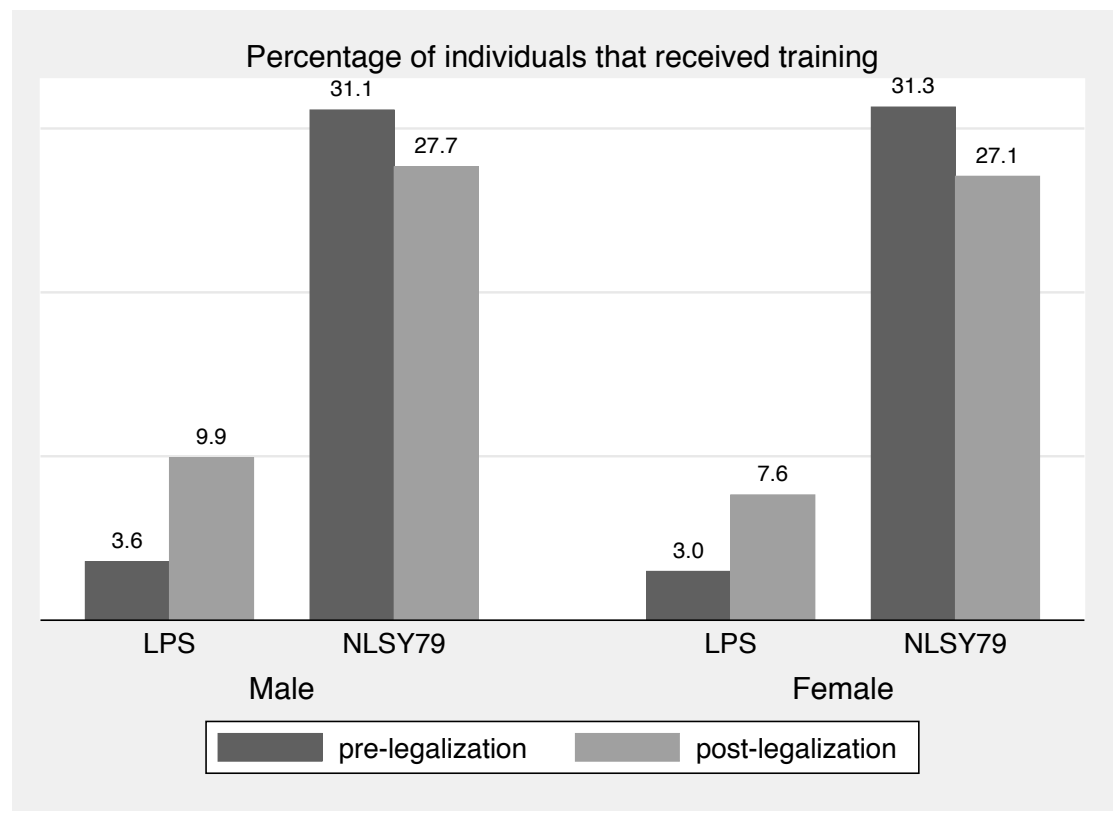

Figure 1 presents the results for training. As shown in this figure, pre and post-legalization measures of training differ substantially between immigrants and natives. As expected, the incidence of training is much larger in the NLSY79 sample than in the LPS sample at all points in time. But after legalization takes place, the incidence of training among legalized immigrants increased (6 percentage points for women, and 5 percentage points for men), while the incidence of training among natives decreased instead ( 4 and 3 percentage points for men and women, respectively). In other words, the before-after (BA) estimate of the effect of legalization on training is 6 percentage points for women and 5 percentage points for men; while the difference-in-difference (DD) estimate is around 9 percentage points for both. These unconditional estimates (computed without covariates) are statistically significant at the $1 \%$ level and suggest there is a positive effect of legalization on human capital accumulation via training. 
Figure 2: Life cycle profile of training incidence.

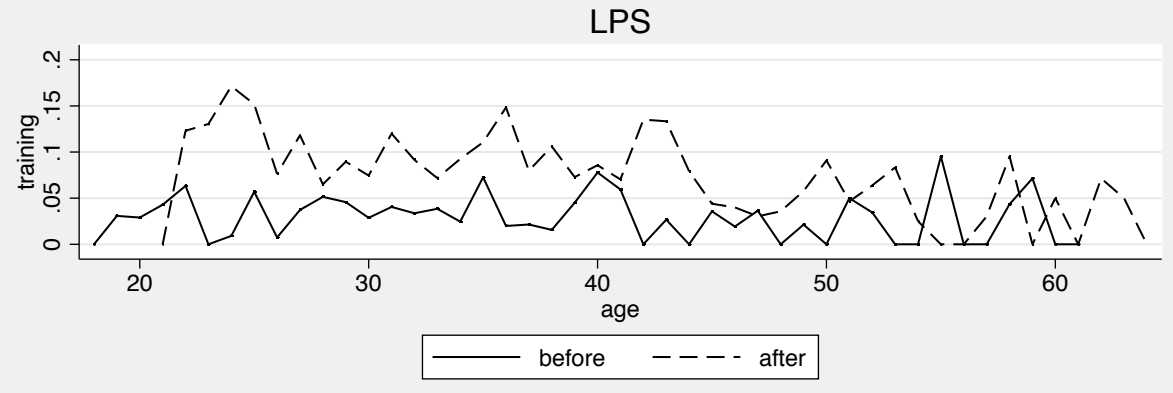

NLSY79

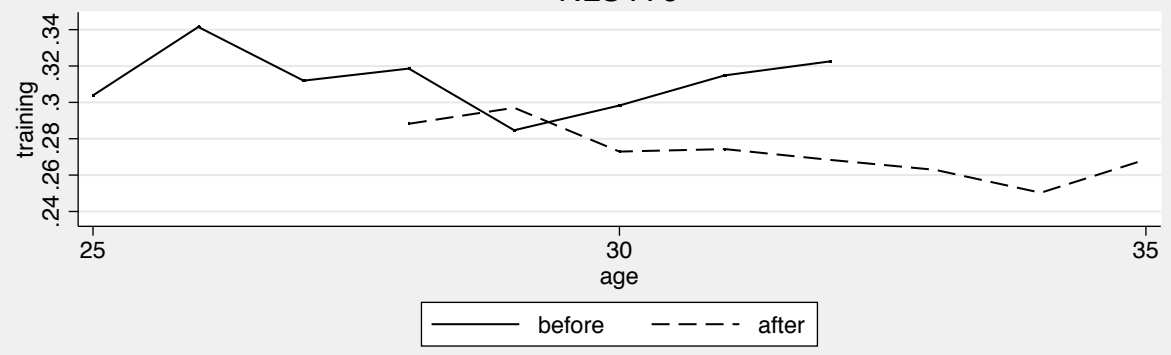

Further inspection of the data shows this difference holds true even after controlling for the effects of age on training. We illustrate this point in figure 2, where we compare the life cycle (or more precisely, age-indexed) paths of training incidence for LPS and NLSY individuals (men and women combined), before and after legalization. As shown in this figure, the life cycle profile of training for individuals in the NLSY79 is decreasing with age and does not suffer important changes between the pre-legalization and the post-legalization periods. This is the typical pattern found in, for instance, Méndez and Sepúlveda (2012), and predicted by Ben Porath (1967). For LPS individuals, in contrast, there are noticeable changes in the training frequency before and after legalization. Before legalization, the profile of training incidence is roughly flat and low. Whereas after legalization, it becomes noticeably higher and decreasing with age. ${ }^{5}$

\footnotetext{
${ }^{5}$ We draw a similar figure using wages as outcome, and find life cycle wage profiles to be typically increasing with age until shortly before retirement. Both the NLSY79 and the LPS samples display this profile before and after legalization. As it was the case using BA and DD estimators, we couldn't find preliminar evidence of a significant effect of legalization on wages, after controlling for age profiles.
} 
Figure 3: Mean of Wages and Occupation Quality by sample, gender, and period.
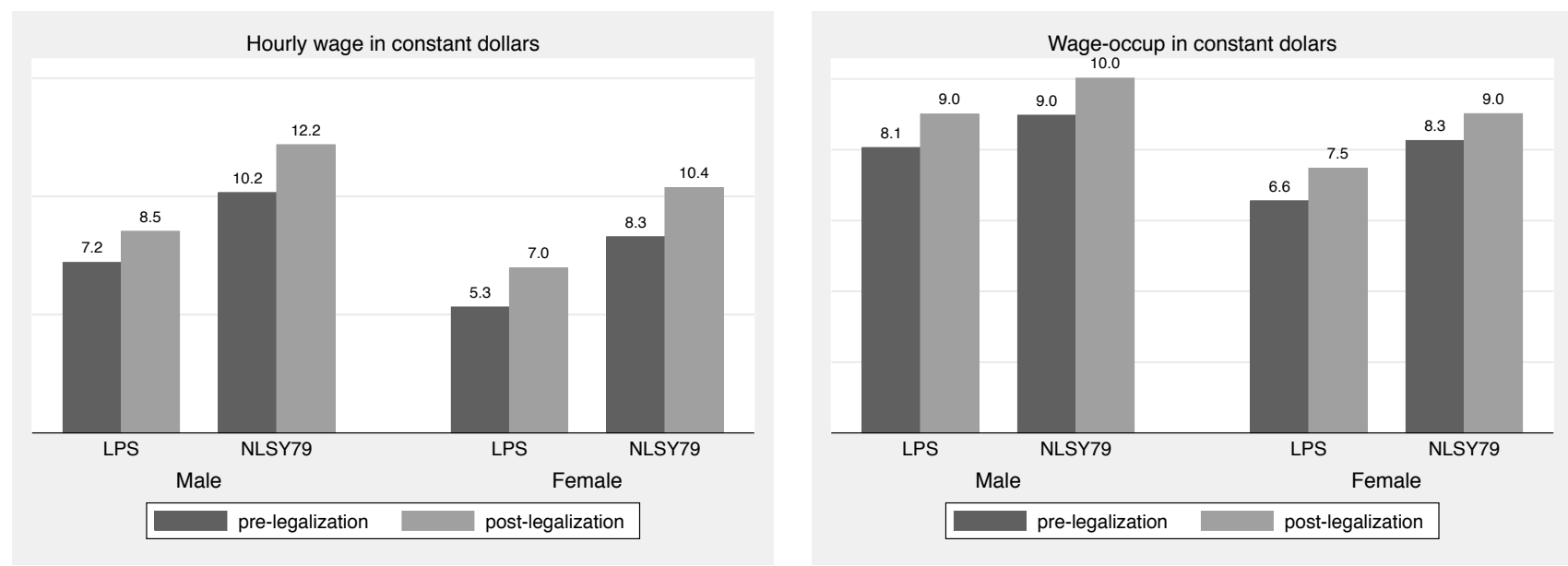

Figure 3, in turn, shows the results for wages and occupational quality. ${ }^{6}$ As expected, wage rates in the NLSY79 are higher than in the LPS at all points in time and our measure of occupational quality (wage-occup) shows individuals in the NLSY sample working in occupations with higher average pay than individuals in the LPS sample. Yet, although BA estimates show significant (at the 1\% level) increases in wages and occupational quality between the pre-legalization and the post-legalization periods, the DD estimates show those increases are roughly the same for both immigrants and natives (DD estimates were not significant at the $1 \%, 5 \%$ or $10 \%$ levels). Thus, these preliminary estimates suggest there was no significant effect of legalization on either wages or occupational quality.

The simple estimates presented so far, however, are likely to be biased due to the potential effects of omitted variables which may be related to training, wages, or occupational quality, and which may vary systematically across samples. Additionally, given we only observe wages and occupation type for those who work, the estimates for wages and occupational quality may also suffer from a sample selection bias. In what follows, we address these potential biases by studying the corresponding differences in training, wages and occupational quality while controlling for the simultaneous effect of variables such as the level of education, labor

\footnotetext{
${ }^{6} \mathrm{~A}$ complete report of unconditional BA and DD estimates for all outcomes analyzed is shown in Table 8 in the appendix.
} 
market participation, and age distribution, and correcting for sample selection in the case of wages and occupational quality.

\section{Econometric Specification and Results}

We attempt to identify the effects of legalization on training, wages, and occupational quality through a difference in differences (DD) approach that compares the outcomes of treated individuals (the non-legal population, LPS respondents) with the outcomes of control individuals (the legal population, NLSY79 respondents), before and after legalization. We deviate from a standard DD framework in that our control group is formed by individuals who were "treated" (legal) in both periods.

Our baseline specification is of the form

$$
\text { Outcome }_{i, t}=\beta_{0}+\beta_{1} \text { period }_{t}+\beta_{2} \text { lps }_{i}+\beta_{3} \text { period }_{t} \times l p s_{i}+\gamma X_{i, t}+\epsilon_{i, t}
$$

Where the variable Outcome $_{i, t}$ is either the training, the wage or the occupational quality of individual $i$ at time $t \in\{$ pre-legalization period, post-legalization period $\}$; period is a dummy variable equal to one if the observed outcome corresponds to the post treatment period and zero otherwise; lps is dummy variable that takes the value of one if the individual belongs to the immigrant sample and zero otherwise; and $X_{i, t}$ is a vector of individual control variables which includes a quadratic polynomial in age. The coefficient on the interaction term, $\beta_{3}$, quantifies the effect of interest.

The critical identifying assumption of the DD estimator in the case under study is that other changes in the economy that took place between the pre-legalization and the postlegalization periods, that affected the outcomes analyzed, and are not captured by our controls, had an equal influence on the LPS and NLSY samples. One way to validate the assumption is to show that the trends in training, wages, and other outcomes, were simi-

lar for both groups before the legalization of 1986. Regrettably, we were unable to obtain 
information on such trends for the non legal population. Up to our knowledge, there were no contemporaneous education or labor policies that affected immigrant and native individuals differently which could invalidate the parallel trends assumption. Another necessary condition for identification is parallel trends on unobservables, such as tastes or preferences, between treated and control individuals. We believe that this is not a critical issue here since only 3 years passed between the pre and post legalization periods.

We first estimate equation (1) using training as the outcome of interest. Since this is a binary variable, we conduct the estimation using both, an OLS linear probability model and a non-linear probability model in which the marginal effects are computed using the methodology for probit distributions proposed by Blundell et al. (2004). The results are presented in table 1. This table shows estimates for the coefficient of interest (the estimated coefficient for $\beta_{3}$ ) only. In the Appendix we report the full results of linear models including estimates for all covariates. Results for estimates of covariates in non-linear models are available upon request.

The first column of table 1 shows estimates for individuals across all educational groups. We observe a large difference in the percentage of individuals that obtained a high school diploma between NLSY79 individuals (74\%), and LPS individuals (22\%). This motivates us to report results separately for "skilled" and "unskilled" individuals, depending on whether they have a high school diploma at the time of interview or not. The second and third columns show estimates for individuals in the unskilled and skilled categories, respectively. The last column shows results for a test of differences between skilled and unskilled workers. Estimates for the aggregate sample are presented on the top panel, followed by the estimates for each gender. The table also shows, in parenthesis, the corresponding standard errors for each estimated coefficient. Standard errors are robust, and clustered at the individual level.

The results indicate that all immigrants experienced significant increases in training incidence after they were granted legal status, with a much larger increase for skilled immigrants in particular. For the total sample, the estimated effect of legalization on training is 7.7 per- 
Table 1: Training: Main results by gender and level of education

\begin{tabular}{|c|c|c|c|c|}
\hline \multicolumn{5}{|c|}{ All } \\
\hline & all & unskilled & skilled & difference \\
\hline & $(1)$ & $(2)$ & $(3)$ & $(4)$ \\
\hline Linear probability & $\begin{array}{c}.077 \\
(.015)^{* * *}\end{array}$ & $\begin{array}{l}.034 \\
(.025)\end{array}$ & $\begin{array}{c}.126 \\
(.024)^{* * *}\end{array}$ & $\begin{array}{c}.092 \\
(.034)^{* * *}\end{array}$ \\
\hline Non-linear probability & $\begin{array}{c}.054 \\
(.006)^{* * *}\end{array}$ & $\begin{array}{c}.039 \\
(.008)^{* * *}\end{array}$ & $\begin{array}{c}.091 \\
(.014)^{* * *}\end{array}$ & $\begin{array}{c}.052 \\
(.016)^{* * *}\end{array}$ \\
\hline Treated obs. & 5748 & 4481 & 1267 & 5748 \\
\hline Control obs. & 3154 & 816 & 2338 & 3154 \\
\hline \multicolumn{5}{|c|}{ Men } \\
\hline & "all & unskilled & skilled & difference \\
\hline & $(1)$ & $(2)$ & $(3)$ & $(4)$ \\
\hline Linear probability & $\begin{array}{c}.109 \\
(.022)^{* * *}\end{array}$ & $\begin{array}{c}.057 \\
(.033)^{*}\end{array}$ & $\begin{array}{c}.175 \\
(.034)^{* * *}\end{array}$ & $\begin{array}{c}.118 \\
(.048)^{* *}\end{array}$ \\
\hline Non-linear probability & $\begin{array}{c}.072 \\
(.008)^{* * *}\end{array}$ & $\begin{array}{c}.051 \\
(.012)^{* * *}\end{array}$ & $\begin{array}{c}.131 \\
(.021)^{* * *}\end{array}$ & $\begin{array}{c}.080 \\
(.025)^{* * *}\end{array}$ \\
\hline Treated obs. & 3068 & 2325 & 743 & 3068 \\
\hline Control obs. & 1524 & 441 & 1083 & 1524 \\
\hline \multicolumn{5}{|c|}{ Women } \\
\hline & 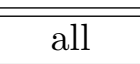 & unskilled & skilled & difference \\
\hline & $(1)$ & $(2)$ & $(3)$ & $(4)$ \\
\hline Linear probability & $\begin{array}{c}.043 \\
(.022)^{* *}\end{array}$ & $\begin{array}{l}.008 \\
(.037)\end{array}$ & $\begin{array}{c}.067 \\
(.032)^{* *}\end{array}$ & $\begin{array}{l}.059 \\
(.049)\end{array}$ \\
\hline Non-linear probability & $\begin{array}{c}.033 \\
(.007)^{* * *}\end{array}$ & $\begin{array}{l}.026 \\
(.011)^{* *}\end{array}$ & $\begin{array}{l}.042 \\
(.021)^{* *}\end{array}$ & $\begin{array}{l}.016 \\
(.024)\end{array}$ \\
\hline Treated obs. & 2680 & 2156 & 524 & 2680 \\
\hline Control obs. & 1630 & 375 & 1255 & 1630 \\
\hline
\end{tabular}

The dependent variable is a binary indicator of treatment. The results for linear probability models are OLS estimates. The results for non-linear probability models are marginal effects computed with Probit estimates following Blundell (2004). Robust standard errors reported in parentheses are clustered at the individual level (analytic standard errors for the linear probability model and bootstrapped standard errors with 1000 replicas for the non-linear probability model). ${ }^{* * *}$ significant at $1 \%$, ${ }^{* *}$ significant at $5 \%,{ }^{*}$ significant at $10 \%$. Column (4) is the difference between skilled and unskilled (column (3) - column (2)). All regressions include age and square of age as covariates.

centage points when using the linear probability model and 5.4 percentage points when using the non-linear model. For skilled immigrants, in contrast, the estimated effect is 12.6 percentage points in the linear model and 9.1 percentage points in the non-linear model; while the corresponding estimates for the unskilled are only 3.4 and 3.9 percentage points. The dif- 
ferences in the coefficients between skilled and unskilled immigrants are significant at the $1 \%$ level and can also be observed when the regressions are run separately for different genders; although they are not statistically significant for women alone. Given we expect training to act as a complement to existing stocks of human capital, the results showing skilled individuals experience greater increases in training after legalization relative to unskilled individuals are not surprising.

In addition, we find the estimated coefficients on legalization to be consistently greater for men than for women; even after controlling for the individual's level of education. As shown in table 1, the OLS estimates indicate legalization increases training by 10.9 percentage points for men in general, while it increases training by only 4.3 percentage points in the case of women. The corresponding estimates for the non-linear model are 7.2 and 3.3, respectively. A similar a difference in the estimated coefficients between men and women is also present when making the comparison separately for the skilled and unskilled groups. The differences are always significant at the $1 \%$ level (not reported).

Next, we estimate equation (1) using wages and occupational quality, respectively, as the outcomes of interest. Wages are measured by the natural logarithm of the observed wages on either period $(\ln ($ wage $))$ and occupational quality is measured by the natural logarithm of the occupation-specific average wage $(\ln ($ wage - occup $))$. As before, only the coefficient of interest (the estimated coefficient for $\beta_{3}$ in equation (1)) is reported and results for other covariates are omitted. In the Appendix we report the full results of linear models including estimates for all covariates. Results for estimates of covariates in non-linear models are available upon request.

A potential sample selection bias arises for wages and occupational quality, as these are observed only for those who work. Thus we conduct the estimations for each of these variables using a Heckman selection model that corrects for potential sample selection biases, as well as a standard OLS technique. Across all regressions, Wald tests for the independence of the wages and employment equations $(\rho=0)$ indicated it is indeed necessary to control 
Table 2: Wage growth: Main results by gender and level of education

\begin{tabular}{lcccc}
\multicolumn{5}{c}{ All } \\
\hline \hline \multirow{2}{*}{ OLS } & all & unskilled & skilled & \multicolumn{2}{c}{ difference } \\
\cline { 2 - 5 } & $(1)$ & $(2)$ & $(3)$ & $(4)$ \\
Heckman & .088 & .159 & .102 & -.057 \\
& $(.023)^{* * *}$ & $(.051)^{* * *}$ & $(.034)^{* * *}$ & $(.062)$ \\
Wald test of $\rho=0$ & .234 & .297 & .239 & -.058 \\
& $(.036)^{* * *}$ & $(.054)^{* * *}$ & $(.051)^{* * *}$ & $(.065)$ \\
Treated obs. & 21.121 & & & 13.701 \\
Control obs. & {$[0.000]$} & & & {$[0.000]$} \\
Censored obs. & 3663 & 2898 & 765 & 3663 \\
\hline \hline
\end{tabular}

\begin{tabular}{|c|c|c|c|c|}
\hline \multicolumn{5}{|c|}{ Men } \\
\hline & בall & unskilled & skilled & difference \\
\hline & $(1)$ & $(2)$ & $(3)$ & $(4)$ \\
\hline$\overline{\mathrm{OLS}}$ & $\begin{array}{l}.045 \\
(.030)\end{array}$ & $\begin{array}{l}.062 \\
(.062)\end{array}$ & $\begin{array}{c}.089 \\
(.044)^{* *}\end{array}$ & $\begin{array}{l}.027 \\
(.076)\end{array}$ \\
\hline Heckman & $\begin{array}{c}.095 \\
(.034)^{* * *}\end{array}$ & $\begin{array}{c}.106 \\
(.056)^{*}\end{array}$ & $\begin{array}{c}.127 \\
(.050)^{* *}\end{array}$ & $\begin{array}{l}.021 \\
(.077)\end{array}$ \\
\hline Wald test of $\rho=0$ & $\begin{array}{l}4.138 \\
{[0.042]}\end{array}$ & & & $\begin{array}{l}2.961 \\
{[0.085]}\end{array}$ \\
\hline Treated obs. & 2374 & 1842 & 532 & 2374 \\
\hline Control obs. & 1189 & 315 & 874 & 1189 \\
\hline Censored obs. & 969 & 570 & 399 & 969 \\
\hline
\end{tabular}

Women

\begin{tabular}{|c|c|c|c|c|}
\hline & all & unskilled & skilled & difference \\
\hline & (1) & $(2)$ & $(3)$ & $(4)$ \\
\hline$\overline{\mathrm{OLS}}$ & $\begin{array}{c}.116 \\
(.033)^{* * *}\end{array}$ & $\begin{array}{c}.278 \\
(.085)^{* * *}\end{array}$ & $\begin{array}{c}.108 \\
(.052)^{* *}\end{array}$ & $\begin{array}{l}-.170 \\
(.100)^{*}\end{array}$ \\
\hline Heckman & $\begin{array}{c}.383 \\
(.048)^{* * *}\end{array}$ & $\begin{array}{c}.548 \\
(.094)^{* * *}\end{array}$ & $\begin{array}{c}.389 \\
(.067)^{* * *}\end{array}$ & $\begin{array}{r}-.159 \\
(.111)\end{array}$ \\
\hline Wald test of $\rho=0$ & $\begin{array}{c}79.821 \\
{[0.000]}\end{array}$ & & & $\begin{array}{c}94.843 \\
{[0.000]}\end{array}$ \\
\hline Treated obs. & 1289 & 1056 & 233 & 1289 \\
\hline Control obs. & 1003 & 145 & 858 & 1003 \\
\hline Censored obs. & 1959 & 1289 & 670 & 1959 \\
\hline
\end{tabular}

The dependent variable is $\ln$ (wage). For the Heckman model, identification is achieved by including marital status and number of children in the family in the selection equation and excluding them from the main equation. Robust standard errors reported in parentheses are clustered at the individual level. *** significant at $1 \%,{ }^{* *}$ significant at $5 \%,{ }^{*}$ significant at $10 \%$. All regressions include age and square of age as covariates. The Wald test of $\rho=0$ is the Wald test for the independence of the wage and employment equations. p-values for the Wald test are reported in brackets. Column (4) is the difference between skilled and unskilled (column (3) - column (2)). In the Appendix we report results of linear models including estimates for covariates, and more details on the selection equation. Results including estimates for covariates in the non-linear model are available upon request. 
Table 3: Occupational quality: Main results by gender and level of education

\begin{tabular}{|c|c|c|c|c|}
\hline \multicolumn{5}{|c|}{ All } \\
\hline & בall & unskilled & skilled & difference \\
\hline & $(1)$ & $(2)$ & $(3)$ & $(4)$ \\
\hline$\overline{\mathrm{OLS}}$ & $\begin{array}{c}.080 \\
(.014)^{* * *}\end{array}$ & $\begin{array}{c}.125 \\
(.024)^{* * *}\end{array}$ & $\begin{array}{c}.108 \\
(.023)^{* * *}\end{array}$ & $\begin{array}{l}-.017 \\
(.034)\end{array}$ \\
\hline Heckman & $\begin{array}{c}.097 \\
(.015)^{* * *}\end{array}$ & $\begin{array}{c}.147 \\
(.027)^{* * *}\end{array}$ & $\begin{array}{c}.107 \\
(.025)^{* * *}\end{array}$ & $\begin{array}{r}-.039 \\
(.036)\end{array}$ \\
\hline Wald test of $\rho=0$ & $\begin{array}{c}23.549 \\
{[0.000]}\end{array}$ & & & $\begin{array}{l}3.631 \\
{[0.057]}\end{array}$ \\
\hline Treated obs. & 3830 & 2951 & 879 & 3830 \\
\hline Control obs. & 2237 & 495 & 1742 & 2237 \\
\hline Censored obs. & 2771 & 1802 & 969 & 2771 \\
\hline
\end{tabular}

\section{Men}

\begin{tabular}{|c|c|c|c|c|}
\hline & $\begin{array}{c}\text { all } \\
(1)\end{array}$ & $\begin{array}{c}\text { unskilled } \\
(2)\end{array}$ & $\begin{array}{l}\text { skilled } \\
(3)\end{array}$ & $\begin{array}{c}\text { difference } \\
(4)\end{array}$ \\
\hline$\overline{\mathrm{OLS}}$ & $\begin{array}{c}.074 \\
(.018)^{* * *}\end{array}$ & $\begin{array}{c}.102 \\
(.028)^{* * *}\end{array}$ & $\begin{array}{c}.104 \\
(.028)^{* * *}\end{array}$ & $\begin{array}{l}.002 \\
(.040)\end{array}$ \\
\hline Heckman & $\begin{array}{l}.047 \\
(.022)^{* *}\end{array}$ & $\begin{array}{c}.155 \\
(.033)^{* * *}\end{array}$ & $\begin{array}{l}.110 \\
(.032)^{* * *}\end{array}$ & $\begin{array}{l}-.045 \\
(.047)\end{array}$ \\
\hline Wald test of $\rho=0$ & $\begin{array}{l}3.374 \\
{[.066]}\end{array}$ & & & $\begin{array}{c}63.501 \\
{[.000]}\end{array}$ \\
\hline Treated obs. & 2420 & 1828 & 592 & 2420 \\
\hline Control obs. & 1128 & 317 & 811 & 1128 \\
\hline Censored obs. & 1009 & 597 & 412 & 1009 \\
\hline
\end{tabular}

Women

\begin{tabular}{|c|c|c|c|c|}
\hline & all & unskilled & skilled & difference \\
\hline & $(1)$ & $(2)$ & $(3)$ & $(4)$ \\
\hline$\overline{\mathrm{OLS}}$ & $\begin{array}{c}.088 \\
(.022)^{* * *}\end{array}$ & $\begin{array}{c}.160 \\
(.042)^{* * *}\end{array}$ & $\begin{array}{c}.120 \\
(.041)^{* * *}\end{array}$ & $\begin{array}{l}-.040 \\
(.059)\end{array}$ \\
\hline Heckman & $\begin{array}{c}.100 \\
(.023)^{* * *}\end{array}$ & $\begin{array}{c}.175 \\
(.044)^{* * *}\end{array}$ & $\begin{array}{l}.124 \\
(.043)^{* * *}\end{array}$ & $\begin{array}{l}-.050 \\
(.061)\end{array}$ \\
\hline Wald test of $\rho=0$ & $\begin{array}{l}5.474 \\
{[.019]}\end{array}$ & & & $\begin{array}{l}.800 \\
{[.049]}\end{array}$ \\
\hline Treated obs. & 1410 & 1123 & 287 & 1410 \\
\hline Control obs. & 1109 & 178 & 931 & 1109 \\
\hline Censored obs. & 1762 & 1205 & 557 & 1762 \\
\hline
\end{tabular}

The dependent variable is $\ln ($ wage - occup). For the Heckman model, identification is achieved by including marital status and number of children in the family in the selection equation and excluding them from the main equation. Robust standard errors reported in parentheses are clustered at the individual level. ${ }^{* * *}$ significant at $1 \%,{ }^{* *}$ significant at $5 \%,{ }^{*}$ significant at $10 \%$. All regressions include age and square of age as covariates. The Wald test of $\rho=0$ is the Wald test for the independence of the wage and employment equations. p-values for the Wald test are reported in brackets. Column (4) is the difference between skilled and unskilled (column (3) - column (2)). In the Appendix we report results of linear models including estimates for covariates, and more details on the selection equation. Results including estimates for covariates in the non-linear model are available upon request. 
for sample selection. Our preferred estimation results, therefore, are those obtained with the Heckman model. Across all regressions, we found no statistically significant difference in the estimated coefficients between skilled and unskilled individuals. We then focus our discussion on the aggregate and gender-specific samples.

Table 2 presents the results for wages. In line with previous literature, we find wages of all legalized individuals (column 1) increase by $8.8 \%$ when using OLS, and $23.4 \%$ when using a the Heckman model. The estimated effect for women is $11.6 \%$ in OLS and a very large $38.3 \%$ in the Heckman model, both significant at the $1 \%$ level. This effect is comparatively weaker for men, at 4.5\% using OLS (insignificant) and 9.5\% using the Heckman model (significant at the $1 \%)$.

Table 3 , in turn, shows the results for our measure of occupational quality. We find legalization leads to significant improvements in occupational quality, that is also differentiated by gender. For the whole sample, the estimated improvement is $8 \%$ using OLS and a $9.7 \%$ using the Heckman model. For women, the estimated gains are 8.8\% using OLS and 10\% using the Heckman model, both significant at the 1\% level. For men, the improvement is $7.4 \%$ when using OLS (significant at the 1\% level), and only $4.7 \%$ (significant at the $5 \%$ ) after correcting for sample selection bias.

Notice that for both, wages and occupational quality, gains are larger for women than for men, while training gains are larger for men. One possible explanation for these results is that women are more likely to move (relative to men) to occupations that better fit their existing skills immediately after legalization and, as a result, they experience a greater shortrun increase in their wages (relative to men) without obtaining as much training as men do. As mentioned before, these differences across men and women open independent lines of research which we are unable to explore with the data at hand. Still, it is worth discussing possible explanations for these conflicting findings.

Our favored candidate explanation conjectures that LPS women have higher discount rates than men, as a result of being in charge of the children in case of marital dissolution. 
As a result they choose to allocate less time to the acquisition of skills, an activity for which they will likely forgo current wages in favor of future wage gains. In the LPS data heads of household cannot be identified, so this conjecture cannot be tested head on, but in results available upon request, we found that children have a negative effect on their parent's training, and that the vast majority of single parent households are headed by women.

\subsection{Sensitivity Analysis}

In order to study whether our results are robust to using alternative definitions of treatment and control groups, we present the results of a sensitivity analysis. Here, we restrict the control group of NLSY79 respondents and the treated group of LPS respondents in several ways: (1) We restrict the NLSY79 sample to only poor respondents of Hispanic origin, (2) we restrict the NLSY79 sample to those who are employed, (3) we restrict the NLSY79 sample to immigrants, and (4) we restrict the LPS sample to respondents with the same age distribution as the NLSY79 respondents. The results are presented in tables 4, 5, and 6 , for training, wages, and occupational quality, respectively. As before, these tables show only the estimated coefficient of interest (the estimated coefficient for $\beta_{3}$ in equation (1)) for each regression. For simplicity, we perform the sensitivity analysis using linear models only. Results of non-linear models are similar and available upon request.

Table 4 shows the alternative estimates of the effect of legalization on training. Columns represent the different gender and education groups, while rows represent alternative control and treatment groups. Note that, when we restrict the NLSY sample to low socio-economic status hispanics (the row labeled "poor hispanics") the results are virtually unchanged. When we use all native workers as controls (row labeled "all workers"), the results are also similar. One possible interpretation of these results is that legalized immigrants experienced gains in the rates of skill acquisition not only compared to similar ethnic groups, but also compared to the US population. However, when our control group is composed of first generation immigrants from the same geographical area as the LPS sample, we find no 
statistically significant effect. In the row labeled "same age", we restrict the LPS sample to the same age span present in the NLS sample, 25 to 35 years of age at any pint in the dataset. Here, effects for women become weaker, being only significant in the case of skilled women. For men, and in the aggregate, the effects are still strong and significant.

In table 5 we present the results on the effect of legalization on wages, when alternative control and treatment groups are used. Changes in both control and treatment groups, lead to estimates that are much the same as the estimates of the baseline model. These results provide strong evidence that there is an aggregate positive effect of legalization on wages, explained mainly by a strong positive effect on the wages of women. ${ }^{7}$ Table 6 presents sensitivity analysis for the effects of legalization on occupational quality. We obtain comparable estimates by using alternative control and treatment groups. These results provide strong evidence that moving to a higher quality occupation is one channel through which immigrants acquire more skills, and experience wage gains after legalization.

\footnotetext{
${ }^{7}$ Results of the sensitivity analysis for wage and occupational quality by educational level are available upon request. In all regressions, differences in the estimated effects between unskilled and skilled workers are not statistically significant.
} 


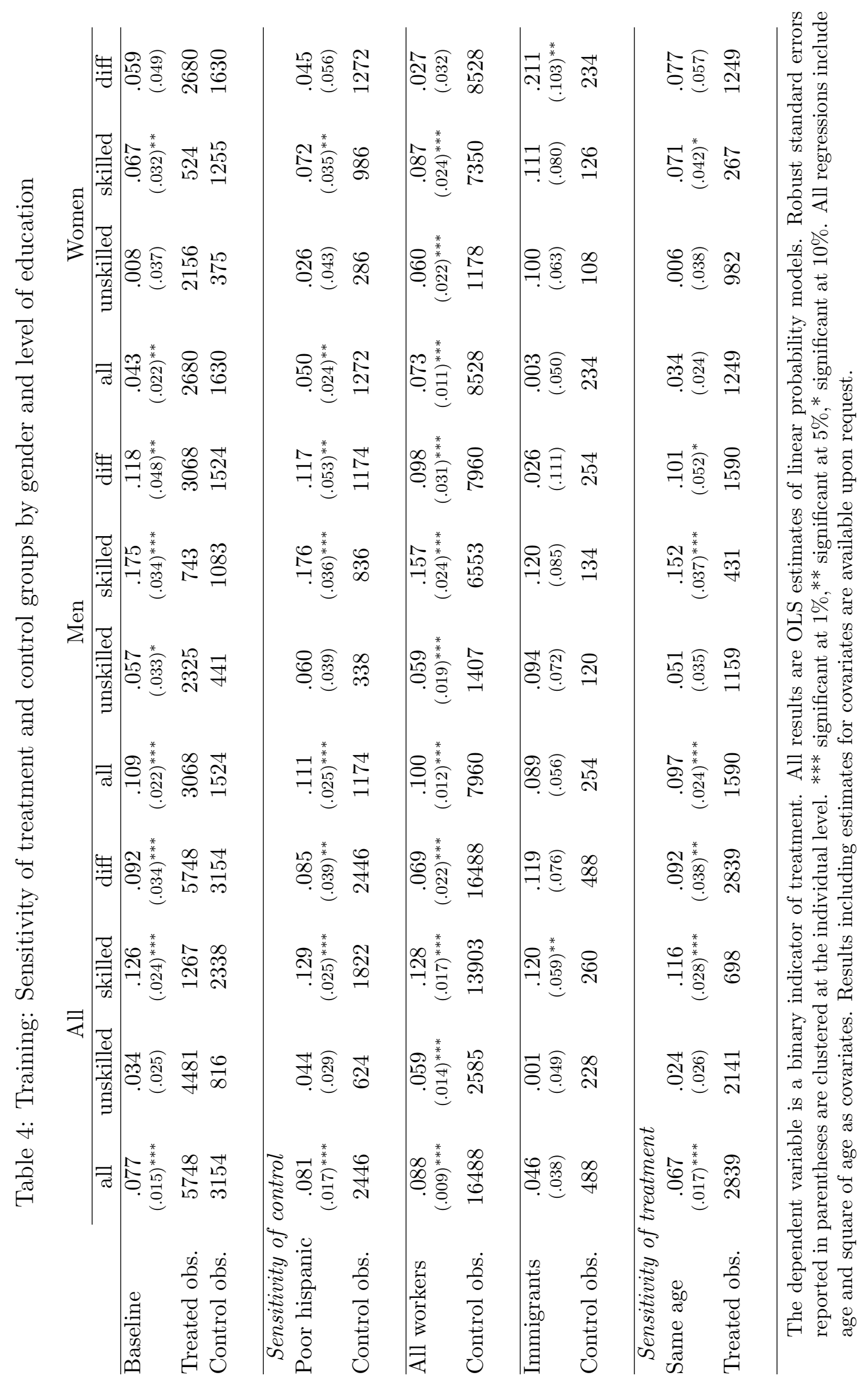


Table 5: Wage growth: Sensitivity of treatment and control groups by gender

\begin{tabular}{lccc} 
& All & Men & Women \\
\cline { 2 - 4 } & $(1)$ & $(2)$ & $(3)$ \\
\hline Baseline & .088 & .045 & .116 \\
& $(.023)^{* * *}$ & $(.030)$ & $(.033)^{* * * *}$ \\
Treated obs. & 3663 & 2374 & 1289 \\
Control obs. & 2192 & 1189 & 1003 \\
\hline Sensitivity of control & .090 & .027 & .147 \\
Poor hispanic & $(.025)^{* * *}$ & $(.033)$ & $(.037)^{* * *}$ \\
Control obs. & 1694 & 910 & 784 \\
\hline All workers & .102 & .052 & .143 \\
& $(.013)^{* * *}$ & $(.017)^{* * *}$ & $(.021)^{* * *}$ \\
Control obs. & 11819 & 6162 & 5657 \\
\hline Immigrants & .144 & .028 & .274 \\
& $(.050)^{* * *}$ & $(.059)$ & $(.086)^{* * *}$ \\
Control obs. & 344 & 210 & 134 \\
\hline Sensitivity of treatment & .083 & & .138 \\
Same age & $(.026)^{* * *}$ & .035 & $(.040)^{* * *}$ \\
Treated obs. & 1885 & 1274 & 611 \\
\hline
\end{tabular}

The dependent variable is $\ln$ (wage). All results are OLS estimates of linear probability models. Robust standard errors reported in parentheses are clustered at the individual level. ${ }^{* * *}$ significant at $1 \%,{ }^{* *}$ significant at 5\%, ${ }^{*}$ significant at $10 \%$. All regressions include age and square of age as covariates. Results including estimates for covariates are available upon request. 
Table 6: Occupational quality: Sensitivity of treatment and control groups by gender

\begin{tabular}{lccc} 
& All & Men & Women \\
\cline { 2 - 4 } & $(1)$ & $(2)$ & $(3)$ \\
\hline Baseline & .080 & .074 & .088 \\
& $(.014)^{* * *}$ & $(.018)^{* * *}$ & $(.022)^{* * *}$ \\
Treated obs. & 3830 & 2420 & 1410 \\
Control obs. & 2237 & 1128 & 1109 \\
\hline Sensitivity of control & .071 & & .085 \\
Poor hispanic & $(.015)^{* * *}$ & $(.019)^{* * *}$ & $(.024)^{* * *}$ \\
& 1737 & 878 & 859 \\
Control obs. & .073 & .056 & .095 \\
All workers & $(.010)^{* * *}$ & $(.011)^{* * *}$ & $(.016)^{* * *}$ \\
& 12043 & 5932 & 6111 \\
Control obs. & .096 & .114 & .071 \\
\hline Immigrants & $(.030)^{* * *}$ & $(.038)^{* * *}$ & $(.047)$ \\
Control obs. & 341 & 191 & 150 \\
\hline Sensitivity of treatment & .064 & & .075 \\
Same age & $(.017)^{* * *}$ & .058 & $(.028)^{* * *}$ \\
Treated obs. & 1949 & 1293 & 656 \\
\hline
\end{tabular}

The dependent variable is is $\ln$ (wage-occup). All results are OLS estimates of linear probability models. Robust standard errors reported in parentheses are clustered at the individual level. ${ }^{* * *}$ significant at $1 \%,{ }^{* *}$ significant at $5 \%,{ }^{*}$ significant at $10 \%$. All regressions include age and square of age as covariates. Results including estimates for covariates are available upon request. 


\section{Conclusion}

This paper presents new evidence regarding the effects of legalization on the training of immigrants who were granted legal status through the U.S. Immigration Reform and Control Act (IRCA) of 1986 and complements previous studies that focused on the effects of legalization programs on wages. Our results show the training incidence of legalized immigrants experiences a jump of 5.4 percentage points compared to our preferred control group, in this case, US residents of Hispanic origin. The post-legalization training incidence more than doubles the pre-legalization training incidence, an enormous gain achieved despite the aging of this group of workers between the two surveys. The gains are larger for men compared to women, and for skilled compared to unskilled workers.

We believe training, as an investment activity, should be a strong predictor of the longer term effects of legalization on the well being of legalized immigrants. In the current debate on immigration reform, our results -within their limited scope- make a clear point that legalization has strong effects on the acquisition of skills by newly legalized immigrants and lead naturally to wonder whether legalization has comparable effects on other investment activities that could in principle be fostered by the effects of legalization. Including investments in children's education, health, and the building of social capital.

As in previous literature, we find evidence of wage gains after legalization. These gains are greater for women than they are for men. In addition, we also find evidence that women benefit more than men from changes in occupational quality immediately after legalization. 


\section{References}

[1] Amuedo-Dorantes, Catalina, Bansak, Cynthia, and Raphael, Steven (2007) "Gender Differences in the Labor Market: Impact of IRCAs Amnesty Provisions" American Economic Review, Vol. 97, No. 2 (May, 2007), pp. 412-416

[2] Ben Porath, Yoram (1967) "The production of human capital and the life cycle of earning" The Journal of Political Economy, vol. 75, no4, pp.352-365.

[3] Blundell R, Dias MC, Meghir C, Reenen JV. (2004). "Evaluating the employment impact of a mandatory job search program." Journal of the European Economic Association, vol. 2, no. 4, pp. 569606.

[4] Borjas, George J. (1985). "Changes in Cohort Quality, and the Earnings of Immigrants" Journal of Labor Economics, vol. 3, no. 4, pp. 463-489.

[5] Borjas, George J. (1995). "The Economic Benefits from Immigration" Journal of Economic Perspectives, vol. 9, no. 2, pp. 3-22.

[6] Chiswick, Barry R. (1978). "The Effects of Americanization on the Earnings of ForeignBorn Men." Journal of Political Economy, vol. 86, no. 5, pp. 897-921.

[7] Chiswick, Barry R. (1980). "Immigrants Earnings Patterns by Sex, Race, and Ethnic Groupings." Monthly Labor Review, vol. 103, no. 10, pp. 22-25.

[8] Dolado, Juan, Goria, Alessandra and Ichino, Andrea (1994). "Immigration, Human Capital and Growth in the Host Country. Evidence from Pooled Country Data." Journal of Population Economics, vol. 7, no. 2, pp. 193-215.

[9] Kaushal, Neera (2006). "Amnesty Programs and the Labor Market Outcomes of Undocumented Workers." The Journal of Human Resources, vol. 41, no. 3, pp. 631-647. 
[10] Kossoudji, Sherrie A. and Cobb-Clark, Deborah A. (2002). "Coming out of the Shadows: Learning about Legal Status and Wages from the Legalized Population." Journal of Labor Economics, vol. 20, no. 3, pp. 598-628.

[11] Lazear, Edward (1976) "Age, Experience and Wage Growth." American Economic Review, vol. 66, No. 4, pp.548-558.

[12] Méndez, Fabio and Sepúlveda, Facundo (2012) "The cyclicality of skill acquisition: evidence from panel data" American Economic Journal: Macroeconomics, vol. 4, No. 3, pp. $128-52$.

[13] Mincer, Jacob (1974) Schooling, Experience, and Earnings. Columbia University Press.

[14] Pan, Ying (2012) "The impact of legal status on immigrants' earnings and human capital: evidence from the IRCA 1986." Journal of Labor Research, vol 33, pp. 119-142.

[15] Passel, Jeffrey S., Cohn, DVera, and Ana Gonzalez-Barrera (2013) "New Estimate: 11.7 million in 2012. Population Decline of Unauthorized Immigrants Stalls, May Have Reversed". Pew Research Centers Hispanic Trends Project.

[16] Rivera-Batiz, Francisco L. (1999) "Undocumented workers in the labor market: An analysis of the earnings of legal and illegal Mexican immigrants in the United States." Journal of Population Economics, vol. 12, no. 1, pp.91-116.

[17] James P. Smith and Barry Edmonston, Editors (1997) The New Americans: Economic, Demographic, and Fiscal Effects of Immigration . Panel on the Demographic and Economic Impacts of Immigration, National Research Council, Division of Behavioral and Social Sciences and Education, Committee on Population. National Academies Press.

[18] Sampaio, Breno, Gustavo Ramos Sampaio, and Yony Sampaio (2013) 'On Estimating the effects of Immigrant Legalization: Do U.S. Agricultural Workers Really Benefit?" American Journal of Agricultural Economics, vol. 95, no. 4, pp.932-48. 
[19] Street, Chris

(2013)

"Europe

legal aliens".

Accessed

April

30,

cracks

down

on

il//www.americanthinker.com/2013/12/europe_cracks_down_on_illegal_aliens.html.

[20] The Economist (2013) "Illegal immigration: Over the top". Oct. 26, 2013. Accessed on March 2, 2014 at http://www.economist.com/news/britain/21588362 - perhaps half-million-people-live-illegally-britain-governments - draconian-new.

[21] The New York Times (2014) "Fleeing Gangs, Children Flee to U.S. Border". July 9, 2014. By Frances Robles

[22] Triandafyllidou, Anna. (2009). Clandestino Project: Undocumented Migration: Counting the Uncountable. Data and Trends Across Europe. Final Report, 23 November 2009. Prepared for the European Commission. Available at: http://clandestino.eliamep. 


\section{Appendix}

\subsection{Questions on training in LPS and NLSY79}

LPS respondents are asked:

"Before you applied for temporary residence, did you ever attend a formal job training program in the United States? Please do not include any informal job training you received while you were working."

"(Since you applied for temporary residence) Have you attended any formal job training program?"

NLSY79 respondents are asked:

“(Besides the training we've already talked about) Since (date of last interview), have you received training from any (other) source, such as the kinds of places listed on this card? For example, training in a business college, nurses program, an apprenticeship program, a vocational-technical institute, or any of these other kinds of sources?" 


\subsection{Tables}

Table 7: Descriptive statistics: means of selected variables

\begin{tabular}{|c|c|c|c|c|c|c|c|c|c|}
\hline & \multicolumn{3}{|c|}{ All } & \multicolumn{3}{|c|}{ LPS } & \multicolumn{3}{|c|}{ NLSY } \\
\hline & pre-treat & post-treat & Diff & pre-treat & post-treat & Diff & pre-treat & post-treat & Diff \\
\hline $\begin{array}{l}\text { Skilled } \\
\text { (proportion) }\end{array}$ & $\begin{array}{l}.39 \\
(.007)\end{array}$ & $\begin{array}{l}.42 \\
(.007)\end{array}$ & $\begin{array}{c}-.02 \\
(.01)^{* *}\end{array}$ & $\begin{array}{l}.21 \\
(.008)\end{array}$ & $\begin{array}{l}.23 \\
(.008)\end{array}$ & $\begin{array}{l}-.02 \\
(.01)^{* *}\end{array}$ & $\begin{array}{l}.73 \\
(.01)\end{array}$ & $\begin{array}{l}.75 \\
(.01)\end{array}$ & $\begin{array}{l}-.02 \\
(.02)\end{array}$ \\
\hline $\begin{array}{l}\text { Employed } \\
\text { (proportion) }\end{array}$ & $\begin{array}{l}.75 \\
(.006)\end{array}$ & $\begin{array}{l}.57 \\
(.007)\end{array}$ & $\begin{array}{c}.19 \\
(.01)^{* * *}\end{array}$ & $\begin{array}{l}.80 \\
(.008)\end{array}$ & $\begin{array}{l}.48 \\
(.009)\end{array}$ & $\begin{array}{c}.32 \\
(.01)^{* * *}\end{array}$ & $\begin{array}{l}.67 \\
(.01)\end{array}$ & $\begin{array}{l}.72 \\
(.01)\end{array}$ & $\begin{array}{c}-.05 \\
(.02)^{* * *}\end{array}$ \\
\hline Age & $\begin{array}{c}31.50 \\
(.12)\end{array}$ & $\begin{array}{c}34.50 \\
(.12)\end{array}$ & $\begin{array}{c}-3 \\
(.16)^{* * *}\end{array}$ & $\begin{array}{c}33.27 \\
(.17)\end{array}$ & $\begin{array}{c}36.27 \\
(.17)\end{array}$ & $\begin{array}{c}-3 \\
(.24)^{* * *}\end{array}$ & $\begin{array}{c}28.26 \\
(.06)\end{array}$ & $\begin{array}{c}31.26 \\
(.06)\end{array}$ & $\begin{array}{c}-3 \\
(.08)^{* * *}\end{array}$ \\
\hline $\begin{array}{l}\text { Women } \\
\text { (proportion) }\end{array}$ & $\begin{array}{l}.52 \\
(.007)\end{array}$ & $\begin{array}{l}.52 \\
(.007)\end{array}$ & $\begin{array}{l}0.00 \\
(.01)\end{array}$ & & & & & & \\
\hline $\begin{array}{l}\text { Cohabitant } \\
\text { (proportion) }\end{array}$ & $\begin{array}{l}.57 \\
(.007)\end{array}$ & $\begin{array}{l}.65 \\
(.007)\end{array}$ & $\begin{array}{c}-.07 \\
(.01)^{* * *}\end{array}$ & $\begin{array}{l}.60 \\
(.009)\end{array}$ & $\begin{array}{l}.70 \\
(.009)\end{array}$ & $\begin{array}{c}-.10 \\
(.01)^{* * *}\end{array}$ & $\begin{array}{l}.52 \\
(.01)\end{array}$ & $\begin{array}{l}.55 \\
(.01)\end{array}$ & $\begin{array}{l}-.03 \\
(.02)^{*}\end{array}$ \\
\hline $\begin{array}{l}\text { Number of } \\
\text { children }\end{array}$ & $\begin{array}{l}1.48 \\
(.02)\end{array}$ & $\begin{array}{l}1.90 \\
(.02)\end{array}$ & $\begin{array}{c}-.42 \\
(.03)^{* * *}\end{array}$ & $\begin{array}{l}1.63 \\
(.03)\end{array}$ & $\begin{array}{l}2.16 \\
(.03)\end{array}$ & $\begin{array}{c}-.53 \\
(.04)^{* * *}\end{array}$ & $\begin{array}{l}1.21 \\
(.03)\end{array}$ & $\begin{array}{l}1.47 \\
(.04)\end{array}$ & $\begin{array}{c}-.27 \\
(.05)^{* * *}\end{array}$ \\
\hline Obs & 5748 & 3154 & 8902 & 3068 & 1524 & 4592 & 2680 & 1630 & 4310 \\
\hline
\end{tabular}

Standard errors reported in parenthesis. The column entitled "Diff" reports the difference in means between the pretreatment and the post-treatment period. These differences are: $* * *$ significant at $1 \%,{ }^{* *}$ significant at $5 \%,{ }^{*}$ significant at $10 \%$. 
Table 8: All outcomes: Before-After and (unconditional) Difference-in-Difference estimates, by gender.

\begin{tabular}{|c|c|c|c|c|c|c|c|}
\hline \multicolumn{8}{|c|}{ Men } \\
\hline & \multicolumn{3}{|c|}{ LPS } & \multicolumn{3}{|c|}{ NLSY79 } & \multirow[t]{2}{*}{ Diff-in-diff } \\
\hline & pre-treat. & post-treat. & diff. & pre-treat. & post-treat. & diff. & \\
\hline & $(1)$ & $(2)$ & $(3)$ & $(4)$ & $(5)$ & $(6)$ & $(7)$ \\
\hline Training & $\begin{array}{c}.036 \\
(.004)^{* * *}\end{array}$ & $\begin{array}{c}.099 \\
(.006)^{* * *}\end{array}$ & $\begin{array}{c}.063 \\
(.008)^{* * * *}\end{array}$ & $\begin{array}{c}.311 \\
(.007)^{* * *}\end{array}$ & $\begin{array}{c}.277 \\
(.007)^{* * *}\end{array}$ & $\begin{array}{l}-.035 \\
(.01)^{* * *}\end{array}$ & $\begin{array}{c}.098 \\
(.013)^{* * *}\end{array}$ \\
\hline Obs. & 2130 & 2130 & 4260 & 3980 & 3980 & 7960 & 12220 \\
\hline Wage & $\begin{array}{l}7.209 \\
(.1)^{* * *}\end{array}$ & $\begin{array}{c}8.527 \\
(.099)^{* * *}\end{array}$ & $\begin{array}{l}1.318 \\
(.14)^{* * *}\end{array}$ & $\begin{array}{c}10.163 \\
(.3)^{* * *}\end{array}$ & $\begin{array}{l}12.185 \\
(.31)^{* * * *}\end{array}$ & $\begin{array}{c}2.022 \\
(.431)^{* * *}\end{array}$ & $\begin{array}{l}-.705 \\
(.454)\end{array}$ \\
\hline Obs. & 1959 & 1181 & 3140 & 3043 & 3119 & 6162 & 9302 \\
\hline $\begin{array}{l}\text { Wage in } \\
\text { Occupation }\end{array}$ & $\begin{array}{c}8.062 \\
(.084)^{* * *}\end{array}$ & $\begin{array}{c}9.011 \\
(.098)^{* * *}\end{array}$ & $\begin{array}{c}.949 \\
(.129)^{* * *}\end{array}$ & $\begin{array}{c}8.977 \\
(.052)^{* * *}\end{array}$ & $\begin{array}{l}10.024 \\
(.061)^{* * *}\end{array}$ & $\begin{array}{l}1.047 \\
(.08)^{* * *}\end{array}$ & $\begin{array}{l}-.098 \\
(.152)\end{array}$ \\
\hline Obs. & 1729 & 1642 & 3371 & 2855 & 3077 & 5932 & 9303 \\
\hline \multicolumn{8}{|c|}{ Women } \\
\hline & \multicolumn{3}{|c|}{ LPS } & \multicolumn{3}{|c|}{ NLSY79 } & Diff-in-diff \\
\hline & pre-treat. & post-treat. & diff. & pre-treat. & post-treat. & diff. & \\
\hline Training & $\begin{array}{c}.03 \\
(.004)^{* * *}\end{array}$ & $\begin{array}{c}.076 \\
(.006)^{* * *}\end{array}$ & $\begin{array}{c}.047 \\
(.007)^{* * * *}\end{array}$ & $\begin{array}{c}.313 \\
(.007)^{* * *}\end{array}$ & $\begin{array}{c}.271 \\
(.007)^{* * *}\end{array}$ & $\begin{array}{l}-.042 \\
(.01)^{* * * *}\end{array}$ & $\begin{array}{c}.089 \\
(.012)^{* * *}\end{array}$ \\
\hline Obs. & 1779 & 1779 & 3558 & 4264 & 4264 & 8528 & 12086 \\
\hline Wage & $\begin{array}{c}5.324 \\
(.084)^{* * *}\end{array}$ & $\begin{array}{c}6.979 \\
(.124)^{* * * *}\end{array}$ & $\begin{array}{l}1.655 \\
(.15)^{* * *}\end{array}$ & $\begin{array}{c}8.296 \\
(.269)^{* * *}\end{array}$ & $\begin{array}{l}10.368 \\
(.239)^{* * * *}\end{array}$ & $\begin{array}{l}2.072 \\
(.36)^{* * *}\end{array}$ & $\begin{array}{c}-.417 \\
(.39)\end{array}$ \\
\hline Obs. & 1195 & 573 & 1768 & 2742 & 2915 & 5657 & 7425 \\
\hline $\begin{array}{l}\text { Wage in } \\
\text { Occupation }\end{array}$ & $\begin{array}{l}6.559 \\
(.09)^{* * *}\end{array}$ & $\begin{array}{c}7.48 \\
(.117)^{* * *}\end{array}$ & $\begin{array}{c}.92 \\
(.148)^{* * *}\end{array}$ & $\begin{array}{c}8.261 \\
(.052)^{* * *}\end{array}$ & $\begin{array}{c}9.018 \\
(.061)^{* * *}\end{array}$ & $\begin{array}{c}.758 \\
(.08)^{* * *}\end{array}$ & $\begin{array}{l}.163 \\
(.168)\end{array}$ \\
\hline Obs. & 1036 & 960 & 1996 & 3028 & 3083 & 6111 & 8107 \\
\hline
\end{tabular}

All results are t test of equality of means. "pre-treat." is the pre-legalization period. "post-treat." is the post-legalization period. Column (3) reports the before-after estimates obtained using treated individuals (LPS respondents), computed as the difference between columns (1) and (2). Column (6) reports the difference between columns (4) and (5). Column (7) reports the unconditional difference-indifference estimates, i.e. the difference between columns (3) and (6). ${ }^{* * *}$ significant at $1 \%,{ }^{* *}$ significant at $5 \%,{ }^{*}$ significant at $10 \%$. 
Table 9: Training: More results by gender and level of education- Estimates in OLS regression

All

\begin{tabular}{|c|c|c|c|c|}
\hline & $\begin{array}{c}\text { all } \\
(1)\end{array}$ & $\begin{array}{c}\text { unskilled } \\
(2)\end{array}$ & $\frac{\text { skilled }}{(3)}$ & $\frac{\text { difference }}{(4)}$ \\
\hline lps $x$ period & $\begin{array}{c}.077 \\
(.015)^{* * *}\end{array}$ & $\begin{array}{l}.034 \\
(.025)\end{array}$ & $\begin{array}{c}.126 \\
(.024)^{* * *}\end{array}$ & $\begin{array}{c}.092 \\
(.034)^{* * *}\end{array}$ \\
\hline period & $\begin{array}{l}-.022 \\
(.015)\end{array}$ & $\begin{array}{l}.008 \\
(.024)\end{array}$ & $\begin{array}{c}-.039 \\
(.018)^{* *}\end{array}$ & $\begin{array}{l}-.047 \\
(.030)\end{array}$ \\
\hline lps & $\begin{array}{c}-.254 \\
(.012)^{* * *}\end{array}$ & $\begin{array}{c}-.124 \\
(.018)^{* * *}\end{array}$ & $\begin{array}{c}-.288 \\
(.016)^{* * *}\end{array}$ & $\begin{array}{c}-.165 \\
(.024)^{* * *}\end{array}$ \\
\hline age & $\begin{array}{l}-.002 \\
(.002)\end{array}$ & $\begin{array}{c}-.0007 \\
(.002)\end{array}$ & $\begin{array}{c}-.0008 \\
(.006)\end{array}$ & $\begin{array}{c}-.0001 \\
(.006)\end{array}$ \\
\hline square of age & $\begin{array}{c}.00002 \\
(.003)\end{array}$ & $\begin{array}{c}-.0007 \\
(.002)\end{array}$ & $\begin{array}{c}-.0006 \\
(.008)\end{array}$ & $\begin{array}{l}.0001 \\
(.008)\end{array}$ \\
\hline Treated obs. & 5748 & 4481 & 1267 & 5748 \\
\hline Control obs. & 3154 & 816 & 2338 & 3154 \\
\hline
\end{tabular}

\section{Men}

\begin{tabular}{|c|c|c|c|c|}
\hline & $\begin{array}{c}\text { all } \\
(1)\end{array}$ & $\frac{\text { unskilled }}{(2)}$ & $\frac{\text { skilled }}{(3)}$ & $\frac{\text { difference }}{(4)}$ \\
\hline lps $x$ period & $\begin{array}{c}.109 \\
(.022)^{* * *}\end{array}$ & $\begin{array}{c}.057 \\
(.033)^{*}\end{array}$ & $\begin{array}{c}.175 \\
(.034)^{* * *}\end{array}$ & $\begin{array}{c}.118 \\
(.048)^{* *}\end{array}$ \\
\hline period & $\begin{array}{l}-.038 \\
(.021)^{*}\end{array}$ & $\begin{array}{l}-.006 \\
(.032)\end{array}$ & $\begin{array}{c}-.053 \\
(.027)^{* *}\end{array}$ & $\begin{array}{l}-.047 \\
(.042)\end{array}$ \\
\hline $\operatorname{lps}$ & $\begin{array}{c}-.259 \\
(.017)^{* * *}\end{array}$ & $\begin{array}{c}-.126 \\
(.024)^{* * *}\end{array}$ & $\begin{array}{c}-.311 \\
(.024)^{* * *}\end{array}$ & $\begin{array}{c}-.185 \\
(.034)^{* * *}\end{array}$ \\
\hline age & $\begin{array}{l}-.003 \\
(.003)\end{array}$ & $\begin{array}{l}.002 \\
(.003)\end{array}$ & $\begin{array}{l}-.016 \\
(.010)^{*}\end{array}$ & $\begin{array}{l}-.018 \\
(.010)^{*}\end{array}$ \\
\hline square of age & $\begin{array}{l}.001 \\
(.004)\end{array}$ & $\begin{array}{l}-.004 \\
(.004)\end{array}$ & $\begin{array}{l}.022 \\
(.014)\end{array}$ & $\begin{array}{l}.025 \\
(.014)^{*}\end{array}$ \\
\hline Treated obs. & 3068 & 2325 & 743 & 3068 \\
\hline Control obs. & 1524 & 441 & 1083 & 1524 \\
\hline
\end{tabular}

\begin{tabular}{|c|c|c|c|c|}
\hline \multicolumn{5}{|c|}{ Women } \\
\hline & all & unskilled & skilled & difference \\
\hline & $(1)$ & $(2)$ & $(3)$ & $(4)$ \\
\hline lps $\mathrm{x}$ period & $\begin{array}{c}.043 \\
(.022)^{* *}\end{array}$ & $\begin{array}{l}.008 \\
(.037)\end{array}$ & $\begin{array}{c}.067 \\
(.032)^{* *}\end{array}$ & $\begin{array}{l}.059 \\
(.049)\end{array}$ \\
\hline period & $\begin{array}{l}-.007 \\
(.021)\end{array}$ & $\begin{array}{l}.024 \\
(.036)\end{array}$ & $\begin{array}{l}-.027 \\
(.025)\end{array}$ & $\begin{array}{l}-.051 \\
(.044)\end{array}$ \\
\hline lps & $\begin{array}{c}-.252 \\
(.016)^{* * *}\end{array}$ & $\begin{array}{c}-.121 \\
(.025)^{* * *}\end{array}$ & $\begin{array}{c}-.266 \\
(.024)^{* * *}\end{array}$ & $\begin{array}{c}-.145 \\
(.035)^{* * *}\end{array}$ \\
\hline age & $\begin{array}{c}-.0009 \\
(.003)\end{array}$ & $\begin{array}{l}-.003 \\
(.003)\end{array}$ & $\begin{array}{l}.011 \\
(.007)\end{array}$ & $\begin{array}{l}.014 \\
(.007)^{*}\end{array}$ \\
\hline square of age & $\begin{array}{c}-.0007 \\
(.003)\end{array}$ & $\begin{array}{l}.002 \\
(.003)\end{array}$ & $\begin{array}{l}-.017 \\
(.009)^{*}\end{array}$ & $\begin{array}{l}-.019 \\
(.009)^{* *}\end{array}$ \\
\hline Treated obs. & 2680 & 2156 & 524 & 2680 \\
\hline Control obs. & 1630 & 375 & 1255 & 1630 \\
\hline
\end{tabular}

The dependent variable is a binary indicator of treatment. Robust standard errors reported in parenthesis clustered at the individual level. ${ }^{* * *}$ significant at $1 \%,{ }^{* *}$ significant at $5 \%,{ }^{*}$ significant at $10 \%$. Column $(4)$ is the difference between high school and more, and less than high school (column (3) - column (2)). 
Table 10: Wage growth: More results by gender and level of education- Estimates in OLS regression

All

\begin{tabular}{|c|c|c|c|c|}
\hline & $\begin{array}{l}\text { all } \\
(1)\end{array}$ & $\begin{array}{c}\text { unskilled } \\
(2)\end{array}$ & $\begin{array}{l}\text { skilled } \\
(3)\end{array}$ & $\begin{array}{c}\text { difference } \\
(4)\end{array}$ \\
\hline lps $x$ period & $\begin{array}{c}.088 \\
(.023)^{* * *}\end{array}$ & $\begin{array}{c}.159 \\
(.051)^{* * *}\end{array}$ & $\begin{array}{c}.102 \\
(.034)^{* * *}\end{array}$ & $\begin{array}{l}-.057 \\
(.062)\end{array}$ \\
\hline period & $\begin{array}{c}.193 \\
(.020)^{* * *}\end{array}$ & $\begin{array}{l}.118 \\
(.050)^{* *}\end{array}$ & $\begin{array}{c}.174 \\
(.023)^{* * *}\end{array}$ & $\begin{array}{l}.057 \\
(.055)\end{array}$ \\
\hline lps & $\begin{array}{l}-.327 \\
(.021)^{* * *}\end{array}$ & $\begin{array}{l}-.231 \\
(.044)^{* * *}\end{array}$ & $\begin{array}{l}-.274 \\
(.028)^{* * *}\end{array}$ & $\begin{array}{l}-.043 \\
(.052)\end{array}$ \\
\hline age & $\begin{array}{c}.048 \\
(.006)^{* * *}\end{array}$ & $\begin{array}{l}.034 \\
(.007)^{* * *}\end{array}$ & $\begin{array}{c}.081 \\
(.012)^{* * *}\end{array}$ & $\begin{array}{c}.046 \\
(.013)^{* * *}\end{array}$ \\
\hline square of age & $\begin{array}{l}-.065 \\
(.008)^{* * *}\end{array}$ & $\begin{array}{l}-.047 \\
(.009)^{* * *}\end{array}$ & $\begin{array}{l}-.097 \\
(.016)^{* * *}\end{array}$ & $\begin{array}{l}-.050 \\
(.018)^{* * *}\end{array}$ \\
\hline Treated obs. & 3663 & 2898 & 765 & 3663 \\
\hline Control obs. & 2192 & 460 & 1732 & 2192 \\
\hline
\end{tabular}

Men

\begin{tabular}{|c|c|c|c|c|}
\hline & $\begin{array}{c}\text { all } \\
(1)\end{array}$ & $\begin{array}{c}\text { unskilled } \\
(2)\end{array}$ & $\begin{array}{l}\text { skilled } \\
(3)\end{array}$ & $\begin{array}{c}\text { difference } \\
(4)\end{array}$ \\
\hline lps x period & $\begin{array}{l}(1) \\
.045 \\
(.030)\end{array}$ & $\begin{array}{l}(2) \\
.062 \\
(.062)\end{array}$ & $\begin{array}{c}(J) \\
.089 \\
(.044)^{* *}\end{array}$ & $\begin{array}{l}(4) \\
.027 \\
(.076)\end{array}$ \\
\hline period & $\begin{array}{c}.171 \\
(.028)^{* * *}\end{array}$ & $\begin{array}{l}.146 \\
(.060)^{* *}\end{array}$ & $\begin{array}{l}.146 \\
(.032)^{* * *}\end{array}$ & $\begin{array}{l}.0003 \\
(.068)\end{array}$ \\
\hline lps & $\begin{array}{l}-.295 \\
(.027)^{* * *}\end{array}$ & $\begin{array}{c}-.208 \\
(.055)^{* * *}\end{array}$ & $\begin{array}{l}-.282 \\
(.037)^{* * *}\end{array}$ & $\begin{array}{l}-.074 \\
(.066)\end{array}$ \\
\hline age & $\begin{array}{c}.065 \\
(.007)^{* * * *}\end{array}$ & $\begin{array}{c}.051 \\
(.008)^{* * *}\end{array}$ & $\frac{.101}{(.016)^{* * *}}$ & $\begin{array}{c}.051 \\
(.017)^{* * *}\end{array}$ \\
\hline square of age & $\begin{array}{l}-.084 \\
(.009)^{* * *}\end{array}$ & $\begin{array}{c}-.066 \\
(.010)^{* * *}\end{array}$ & $\begin{array}{l}-.125 \\
(.021)^{* * *}\end{array}$ & $\begin{array}{l}-.059 \\
(.023)^{* *}\end{array}$ \\
\hline Treated obs. & 2374 & 1842 & 532 & 2374 \\
\hline Control obs. & 1189 & 315 & 874 & 1189 \\
\hline
\end{tabular}

\begin{tabular}{|c|c|c|c|c|}
\hline \multicolumn{5}{|c|}{ Women } \\
\hline & all & unskilled & skilled & difference \\
\hline & $(1)$ & $(2)$ & $(3)$ & $(4)$ \\
\hline lps x period & $\begin{array}{c}.116 \\
(.033)^{* * *}\end{array}$ & $\begin{array}{c}.278 \\
(.085)^{* * *}\end{array}$ & $\begin{array}{c}.108 \\
(.052)^{* *}\end{array}$ & $\begin{array}{l}-.170 \\
(.100)^{*}\end{array}$ \\
\hline period & $\begin{array}{c}.221 \\
(.029)^{* * *}\end{array}$ & $\begin{array}{l}.056 \\
(.083)\end{array}$ & $\frac{.214}{(.032)^{* * *}}$ & $\begin{array}{l}.158 \\
(.089)^{*}\end{array}$ \\
\hline lps & $\begin{array}{l}-.429 \\
(.030)^{* * *}\end{array}$ & $\begin{array}{c}-.210 \\
(.063)^{* * *}\end{array}$ & $\begin{array}{l}-.355 \\
(.042)^{* * *}\end{array}$ & $\begin{array}{l}-.144 \\
(.076)^{*}\end{array}$ \\
\hline age & $\begin{array}{c}.029 \\
(.009)^{* * *}\end{array}$ & $\begin{array}{l}.020 \\
(.010)^{*}\end{array}$ & $\begin{array}{c}.045 \\
(.017)^{* * *}\end{array}$ & $\begin{array}{l}.025 \\
(.020)\end{array}$ \\
\hline square of age & $\begin{array}{c}-.040 \\
(.012)^{* * *}\end{array}$ & $\begin{array}{l}-.030 \\
(.014)^{* *}\end{array}$ & $\begin{array}{l}-.049 \\
(.022)^{* *}\end{array}$ & $\begin{array}{l}-.019 \\
(.026)\end{array}$ \\
\hline Treated obs. & 1289 & 1056 & 233 & 1289 \\
\hline Control obs. & 1003 & 145 & 858 & 1003 \\
\hline
\end{tabular}

Robust standard errors reported in parenthesis are clustered at the individual level. ${ }^{* * *}$ significant at $1 \%$, ${ }^{*}$ significant at $5 \%, *$ significant at $10 \%$. Depedent variable is $\ln$ (wage). Column (4) is the difference between high school and more, and less than high school (column (3) - column (2)). 
Table 11: Occupational quality: More results by gender and level of education- Estimates in OLS regression

All

\begin{tabular}{|c|c|c|c|c|}
\hline & $\begin{array}{c}\text { all } \\
(1)\end{array}$ & $\frac{\text { unskilled }}{(2)}$ & $\begin{array}{l}\text { skilled } \\
(3)\end{array}$ & $\begin{array}{c}\text { difference } \\
(4)\end{array}$ \\
\hline lps x period & $\begin{array}{c}.080 \\
(.014)^{* * *}\end{array}$ & $\begin{array}{c}.125 \\
(.024)^{* * *}\end{array}$ & $\begin{array}{c}.108 \\
(.023)^{* * *}\end{array}$ & $\begin{array}{l}-.017 \\
(.034)\end{array}$ \\
\hline period & $\begin{array}{c}-.0009 \\
(.012)\end{array}$ & $\begin{array}{l}-.058 \\
(.022)^{* *}\end{array}$ & $\begin{array}{l}-.011 \\
(.014)\end{array}$ & $\begin{array}{l}.046 \\
(.026)^{*}\end{array}$ \\
\hline lps & $\begin{array}{l}-.275 \\
(.012)^{* * *}\end{array}$ & $\begin{array}{c}-.185 \\
(.021)^{* * *}\end{array}$ & $\begin{array}{l}-.240 \\
(.019)^{* * *}\end{array}$ & $\begin{array}{l}-.055 \\
(.028)^{* *}\end{array}$ \\
\hline age & $\begin{array}{l}.091 \\
(.004)^{* * *}\end{array}$ & $\begin{array}{l}.081 \\
(.005)^{* * *}\end{array}$ & $\begin{array}{l}.122 \\
(.009)^{* * *}\end{array}$ & $\begin{array}{l}.042 \\
(.010)^{* * *}\end{array}$ \\
\hline square of age & $\begin{array}{l}-.106 \\
(.006)^{* * *}\end{array}$ & $\begin{array}{l}-.092 \\
(.007)^{* * *}\end{array}$ & $\begin{array}{l}-.143 \\
(.013)^{* * *}\end{array}$ & $\begin{array}{l}-.051 \\
(.015)^{* * *}\end{array}$ \\
\hline Treated obs. & 3830 & 2951 & 879 & 3830 \\
\hline Control obs. & 2237 & 495 & 1742 & 2237 \\
\hline
\end{tabular}

Men

\begin{tabular}{|c|c|c|c|c|}
\hline & $\begin{array}{c}\text { all } \\
(1)\end{array}$ & $\begin{array}{c}\text { unskilled } \\
(2)\end{array}$ & $\begin{array}{l}\text { skilled } \\
(3)\end{array}$ & $\begin{array}{c}\text { difference } \\
(4)\end{array}$ \\
\hline lps x period & $\begin{array}{c}.074 \\
(.018)^{* * *}\end{array}$ & $\begin{array}{c}.102 \\
(.028)^{* * *}\end{array}$ & $\begin{array}{c}.104 \\
(.028)^{* * *}\end{array}$ & $\begin{array}{l}.002 \\
(.040)\end{array}$ \\
\hline period & $\begin{array}{l}-.016 \\
(.016)\end{array}$ & $\begin{array}{l}-.057 \\
(.026)^{* *}\end{array}$ & $\begin{array}{l}-.023 \\
(.019)\end{array}$ & $\begin{array}{l}.034 \\
(.033)\end{array}$ \\
\hline lps & $\begin{array}{l}-.258 \\
(.015)^{* * *}\end{array}$ & $\begin{array}{c}-.174 \\
(.024)^{* * *}\end{array}$ & $\begin{array}{c}-.256 \\
(.022)^{* * *}\end{array}$ & $\begin{array}{l}-.081 \\
(.033)^{* *}\end{array}$ \\
\hline age & $\begin{array}{l}.101 \\
(.005)^{* * *}\end{array}$ & $\begin{array}{c}.092 \\
(.006)^{* * *}\end{array}$ & $\begin{array}{c}.129 \\
(.011)^{* * * *}\end{array}$ & $\begin{array}{l}.037 \\
(.013)^{* * *}\end{array}$ \\
\hline square of age & $\begin{array}{l}-.114 \\
(.007)^{* * *}\end{array}$ & $\begin{array}{l}-.102 \\
(.008)^{* * *}\end{array}$ & $\begin{array}{l}-.149 \\
(.016)^{* * *}\end{array}$ & $\begin{array}{l}-.047 \\
(.018)^{* * *}\end{array}$ \\
\hline Treated obs. & 2420 & 1828 & 592 & 2420 \\
\hline Control obs. & 1128 & 317 & 811 & 1128 \\
\hline
\end{tabular}

\begin{tabular}{|c|c|c|c|c|}
\hline \multicolumn{5}{|c|}{ Women } \\
\hline & all & unskilled & skilled & difference \\
\hline & $(1)$ & $(2)$ & $(3)$ & $(4)$ \\
\hline lps x period & $\begin{array}{c}.088 \\
(.022)^{* * *}\end{array}$ & $\begin{array}{c}.160 \\
(.042)^{* * *}\end{array}$ & $\begin{array}{c}.120 \\
(.041)^{* * *}\end{array}$ & $\begin{array}{l}-.040 \\
(.059)\end{array}$ \\
\hline period & $\begin{array}{l}.015 \\
(.017)\end{array}$ & $\begin{array}{l}-.071 \\
(.039)^{*}\end{array}$ & $\begin{array}{l}.004 \\
(.021)\end{array}$ & $\begin{array}{l}.074 \\
(.044)^{*}\end{array}$ \\
\hline lps & $\begin{array}{l}-.342 \\
(.019)^{* * *}\end{array}$ & $\begin{array}{l}-.201 \\
(.035)^{* * *}\end{array}$ & $\begin{array}{l}-.280 \\
(.034)^{* * * *}\end{array}$ & $\begin{array}{l}-.080 \\
(.048)^{*}\end{array}$ \\
\hline age & $\begin{array}{c}.077 \\
(.006)^{* * * *}\end{array}$ & $\begin{array}{c}.069 \\
(.006)^{* * *}\end{array}$ & $\begin{array}{l}.110 \\
(.015)^{* * *}\end{array}$ & $\begin{array}{c}.041 \\
(.017)^{* *}\end{array}$ \\
\hline square of age & $\begin{array}{c}-.093 \\
(.007)^{* * *}\end{array}$ & $\begin{array}{c}-.082 \\
(.008)^{* * *}\end{array}$ & $\begin{array}{l}-.132 \\
(.022)^{* * * *}\end{array}$ & $\begin{array}{l}-.050 \\
(.024)^{* *}\end{array}$ \\
\hline Treated obs. & 1410 & 1123 & 287 & 1410 \\
\hline Control obs. & 1109 & 178 & 931 & 1109 \\
\hline
\end{tabular}

Robust standard errors reported in parenthesis are clustered at the individual level. ${ }^{* * *}$ significant at $1 \%$, ${ }^{*}$ significant at $5 \%,{ }^{*}$ significant at $10 \%$. Dependent variable is $\ln ($ wage $)$. Column (4) is the difference between high school and more, and less than high school (column (3) - column (2)). 
Table 12: Wage growth: More results by gender and level of education- Heckman selection model

\begin{tabular}{|c|c|c|c|c|}
\hline \multicolumn{5}{|c|}{ All } \\
\hline & base & unskilled & skilled & difference \\
\hline & $(1)$ & $(2)$ & $(3)$ & $(4)$ \\
\hline lps x period & $\begin{array}{c}.234 \\
(.036)^{* * *}\end{array}$ & $\begin{array}{c}.297 \\
(.054)^{* * *}\end{array}$ & $\begin{array}{c}.239 \\
(.051)^{* * *}\end{array}$ & $\begin{array}{c}-.058 \\
(.065)\end{array}$ \\
\hline Obs. & 8673 & 5138 & 3535 & 8673 \\
\hline Censored obs. & 2928 & 1859 & 1069 & 2928 \\
\hline$\lambda$ & -.275 & & & -.255 \\
\hline $\operatorname{se}(\lambda)$ & .054 & & & .063 \\
\hline Wald test of $\rho=0$ & 21.121 & & & 13.701 \\
\hline Wald test pvalue & $4.31 \mathrm{e}-06$ & & & .0002 \\
\hline \multicolumn{5}{|c|}{ Men } \\
\hline & base & unskilled & skilled & difference \\
\hline & $(1)$ & (2) & $(3)$ & (4) \\
\hline lps x period & $\begin{array}{c}.095 \\
.034)^{* * *}\end{array}$ & $\begin{array}{l}.106 \\
(.056)^{*}\end{array}$ & $\begin{array}{c}.127 \\
(.050)^{* *}\end{array}$ & $\begin{array}{l}.021 \\
(.077)\end{array}$ \\
\hline Obs. & 4449 & 2668 & 1781 & 4449 \\
\hline Censored obs. & 969 & 570 & 399 & 969 \\
\hline$\lambda$ & -.098 & & & -.082 \\
\hline $\operatorname{se}(\lambda)$ & .046 & & & .046 \\
\hline Wald test of $\rho=0$ & 4.138 & & & 2.961 \\
\hline Wald test pvalue & .042 & & & .085 \\
\hline \multicolumn{5}{|c|}{ Women } \\
\hline & base & unskilled & skilled & difference \\
\hline & $(1)$ & $(2)$ & $(3)$ & (4) \\
\hline lps x period & $\begin{array}{c}.383 \\
(.048)^{* * *}\end{array}$ & $\begin{array}{c}.548 \\
(.094)^{* * *}\end{array}$ & $\begin{array}{c}.389 \\
(.067)^{* * *}\end{array}$ & $\begin{array}{c}-.159 \\
(.111)\end{array}$ \\
\hline Obs. & 4224 & 2470 & 1754 & 4224 \\
\hline Censored obs. & 1959 & 1289 & 670 & 1959 \\
\hline$\lambda$ & -.443 & & & -.436 \\
\hline $\operatorname{se}(\lambda)$ & .039 & & & .035 \\
\hline Wald test of $\rho=0$ & 79.821 & & & 94.843 \\
\hline Wald test pvalue & $4.10 \mathrm{e}-19$ & & & $2.06 \mathrm{e}-22$ \\
\hline
\end{tabular}

The dependent variable is $\ln$ (wage). Identification is achieved by including marital status and number of children in the family in the selection equation and excluding them from the main equation. Robust standard errors reported in parentheses are clustered at the individual level. $* * *$ significant at $1 \%,{ }^{* *}$ significant at 5\%, ${ }^{*}$ significant at $10 \%$. All regressions include age and square of age as covariates. Column (4) is the difference between high school and more, and less than high school (column (3) - column (2)). 
Table 13: Occupational quality: More results by gender and level of education- Heckman selection models

\begin{tabular}{|c|c|c|c|c|}
\hline \multicolumn{5}{|c|}{ All } \\
\hline & base & unskilled & skilled & difference \\
\hline & $(1)$ & $(2)$ & $(3)$ & $(4)$ \\
\hline lps $x$ period & $\begin{array}{c}.097 \\
(.015)^{* * *}\end{array}$ & $\begin{array}{c}.147 \\
(.027)^{* * *}\end{array}$ & $\begin{array}{c}.107 \\
(.025)^{* * *}\end{array}$ & $\begin{array}{c}-.039 \\
(.036)\end{array}$ \\
\hline Obs. & 8673 & 5138 & 3535 & 8673 \\
\hline Censored obs. & 2771 & 1802 & 969 & 2771 \\
\hline$\lambda$ & -.136 & & & -.099 \\
\hline $\operatorname{se}(\lambda)$ & .027 & & & .051 \\
\hline Wald test of $\rho=0$ & 23.549 & & & 3.631 \\
\hline Wald test pvalue & $1.22 \mathrm{e}-06$ & & & .057 \\
\hline \multicolumn{5}{|c|}{ Men } \\
\hline & base & unskilled & skilled & difference \\
\hline & $(1)$ & $(2)$ & $(3)$ & $(4)$ \\
\hline lps $x$ period & $\begin{array}{l}.047 \\
(.022)^{* *}\end{array}$ & $\begin{array}{c}.155 \\
(.033)^{* * *}\end{array}$ & $\begin{array}{c}.110 \\
(.032)^{* * *}\end{array}$ & $\begin{array}{c}-.045 \\
(.047)\end{array}$ \\
\hline Obs. & 4449 & 2668 & 1781 & 4449 \\
\hline Censored obs. & 1009 & 597 & 412 & 1009 \\
\hline$\lambda$ & .162 & & & -.260 \\
\hline $\operatorname{se}(\lambda)$ & .081 & & & .024 \\
\hline Wald test of $\rho=0$ & 3.374 & & & 63.501 \\
\hline Wald test pvalue & .066 & & & $1.60 \mathrm{e}-15$ \\
\hline \multicolumn{5}{|c|}{ "Women } \\
\hline & base & unskilled & skilled & / difference \\
\hline & $(1)$ & $(2)$ & $(3)$ & $(4)$ \\
\hline lps $x$ period & $\begin{array}{c}.100 \\
(.023)^{* * *}\end{array}$ & $\begin{array}{c}.175 \\
(.044)^{* * *}\end{array}$ & $\begin{array}{c}.124 \\
(.043)^{* * *}\end{array}$ & $\begin{array}{c}-.050 \\
(.061)\end{array}$ \\
\hline Obs. & 4224 & 2470 & 1754 & 4224 \\
\hline Censored obs. & 1762 & 1205 & 557 & 1762 \\
\hline$\lambda$ & -.072 & & & -.044 \\
\hline $\operatorname{se}(\lambda)$ & .031 & & & .049 \\
\hline Wald test of $\rho=0$ & 5.474 & & & .800 \\
\hline Wald test pvalue & .019 & & & .371 \\
\hline
\end{tabular}

The dependent variable is $\ln ($ wage - occup). Identification is achieved by including marital status and number of children in the family in the selection equation and excluding them from the main equation. Robust standard errors reported in parentheses are clustered at the individual level. ${ }^{* * *}$ significant at $1 \%,{ }^{* *}$ significant at $5 \%,{ }^{*}$ significant at $10 \%$. All regressions include age and square of age as covariates. Column (4) is the difference between high school and more, and less than high school (column (3) column (2)). 